

NEW METHODS OF TRANSPORTING EGGS AND FISH

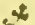

By Walter S. Kincaid

Gencral Suporintendent of State Fish Hatcheries, Denver, Colo.

$+$

Paper presented before the Fourth International Fishery Congress held at Washington, U. S. A., September 22 to 26, 1908

BULLETIN OF THE BUREAU OF FISHERIES : : : : : : VOL. XXVIII, P. 1037-1039

Document No.706 : : : : : : : : : : : : : : : : : : Issued April, 1910 


$$
5 x
$$

1

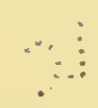




\title{
NEW METHODS OF TRANSPORTING EGGS AND FISH.
}

\author{
BY WALTER S. KINCAID, \\ General Superintendent of State Fish Hatcheries, Dinver, Colo. \\ HANDLING GREEN EGGS OF TROUT.
}

This method consists of packing the eggs in a case containing + trays, each about 8 by 20 inches, each tray containing 10 cells about 4 inches square, or 40 cells in each crate, the bottom of each tray covered with brass screen cloth to allow water to drain off and also to prevent rust. Eacli cell carries 4,000 green trout eggs, and there are thus 160,000 in the entire crate. In packing the eggs in the cells, make a nest of moss in each cell; place clotl down firmly in cell, leaving top of cell open; pour just 4,ooo eggs in cell, fold cloth carefully over them, and then fill cell to top with moss. Before placing trays in case make cushion of about one-half an inch of 1 noss in bottom of case. After placing trays in case set perforated ice tray on top of eggs, fill ice tray with chopped ice, and the eggs are ready for transportation either by pack horse, wagon, or rail.

This crate when packed ready for shipping weiglıs 8 i pounds.

The advantage claimed for this method is the economy in weight and space in handling green trout eggs successfully either on pack horses, by wagon, or by rail.

HANDLING EYED TROUT EGGS.

This method consists in removing the cell trays and using the flat tray before described.

What is claimed for this method is again the economy in weight and space. The case being canvas-lined and with heavy felt cloth attaclied to the zine inner lining, and having an air space between that and the egg trays, insures the eggs against heat or cold while in transit when properly iced and cared for.

This case when packed ready for transportation weiglis about So pounds.

APPLIANCE FOR AERATING WATER IN TRANSPORTATION.

This device consists in attacliments to the bottom of the can, one oil each side about one-half inch thick, causing the can to rock continually from side to side with the slightest motion of the car, the water in the can assisting in the motion after once started, thus aerating itself without the necessity of an assistant while the train is in motion.

We claim that this device is very effective, simple, and inexpensive. 
LIBRARY OF CONGRESS 